\author{
Łukasz Guzek \\ (- https://orcid.org/0000-0002-6101-0953 \\ The Academy of Fine Arts in Gdańsk \\ lukasz.guzek@asp.gda.pl
}

\title{
NAKED FORMS - A CULTURAL CHALLENGE
}

\begin{abstract}
The starting point of the article is the Festival of Naked Forms which is organized by Lenka Klodova in Prague (and occasionally in other cities). The curator gave the festival a monothematic character. It concerns nudity in performance art, i.e. in a live form. The festival has been held every year since 2016. At that time, the festival presented a huge variety of performance forms, artistic means and media hybrids. The festival's documentation is the basis for research into the nude form in live art. In interpretative methodology, the naked form has been associated with forms of presenting libido and the 'principle of pleasure', as well as the visual aspect of a work of art and the role of 'gaze' in the very specific performance art work. The point of reference is both surreal art and the contemporary relationship of art to pornography. In conclusion, the subversive, challenging or political power of naked forms and their ability to make changes in culture is indicated.
\end{abstract}

Keywords: performance art, pornography, gaze, pleasure principle, posthuman, gender, Festival of Naked Forms, Lenka Klodova

Lenka Klodová raised the banner of the Festival of Naked Forms [Festival nahých forem - FNAF] for the first time in 2014 in Divus (a former state factory) which became Nová Perla (a private venue for creative business and culture), located in Vranénad Vltavou [Vltava], Prague zone. Her initial performance was to run (naked) around the place where the festival was born. The banner featured the FNAF festival logo: figures-signs depicting a woman and a man simultaneously throwing their dessous into a garbage can. It is a clear declaration of shedding the bonds of cultural norms that bind the individual; a declaration of freedom and independence, both social and artistic. The banner as an object - a visual symbol - belongs to the category of heroic icono- 
graphy. It is a symbol of power, its mighty force or agency. The raising of the banner is a declaration of the sovereignty of action, marking the position here and now in time and space, thus confirming one's presence. At the same time, the raised banner establishes the centre around which everything circulates the festival is monothematic. When raising a banner, the artist says, here I am and I am creating. This performance was the curator's manifesto. She called this action the 'curatorial run' opening the first festival and its history.

In 2020, during the 6th edition of the Festival of Naked Forms, the banner was raised by the young performer Darina Alster. The banner featured photographic portraits of feminist activists, while the artist herself performed as a goddess-heroine. The Serpent (tattooed) crawled over her body... The assistants - priests of her cult covered her naked body with verses of hermetic texts. Today, the heroine's banner still points to the central ideas around which the revaluation of cultural discourses revolves. The reference point for the creators of the Nová Perla (New Pearl) venue was the ideal 'dream kingdom' described in Alfred Kubin's book The Other Side (1908), "where everything is à rebours in the end anyway."1 The existing reality is not the only one - you just need to be aware of it. Such awareness is the basis for generating change on an individual, social and cultural level. The dream, or the subconscious, is also real. Kubin, a contemporary of Sigmund Freud, used a bipolar scheme, but also the possibility of transition between oppositions or contradictions. Surrealism, following Freud, assumes that the existing state of affairs is one of the possible ones and can be changed. As André Breton said in his Manifesto of Surrealism: "On the basis of these discoveries, a current of opinion is finally forming by means of which the human explorer will be able to carry his investigation much further, authorized as he will henceforth be not to confine himself solely to the most summary realities." ${ }^{2}$ More specifically, it is about the possibility of a paradigmatic change and therefore a holistic one, when the replacement of the existing state of affairs takes place. For the purposes of reflecting on this festival, we can learn from the lessons of surrealism that the obvious can be questioned. Let us add to this one more paradigm of the Freudian concept: libido as a force that determines our actions. Surrealism fully consciously used the methods of mental automatism, the 'pleasure principle,' or the body's action on the subconscious level (id). The naked form is a method that uses these principles. The

1 http://htm.divus.cz/praha/en/article/alfred-kubin-a-few-notes-inspired-by-the-exhibition - a manifesto about the inspiration by Alfred Kubin on the Divus website.

2 After the translation of the "Manifesto of Surrealism" (one of several available): https://www. ubu.com/historical/breton/Breton-Andre_First-Manifesto-of-Surrealism_1924.pdf.In print, see e.g. 100 Artist's Manifestos From the Futurists to the Stuckists, selected by A. Danchev, Penguin Books 2011, pp. 241-274. 
naked body, used consciously here as a means of artistic expression, becomes a critical tool. By acting through the naked body, we reach the basics of culture. We are guided by the 'pleasure principle' which, as it turns out, has a critical power. By means of nudity, the leading assumptions of culture are challenged, those that seem to be taken for granted. The naked form is a tool of doubt ( $d u$ bito as a condition of cogito) and therefore of critical reflection, because it is situated on the limes of the world we live in.

Feminism as an approach to the cultural politics of (any) power leads us to realize the deep sources of European culture. In practice, the task of updating this knowledge in contemporary art discourse (as Linda Nochlin postulated in Why Have There Been No Great Women Artists?) $)^{3}$ relies on rewriting and comprehensive reinterpretation of culture and art. The banner raised by Klodová marks a change in the cultural paradigm of artistic production in Western culture. Nudity is the catalyst for these changes. Her art and the festival as her project challenge the prevailing culture. Nochlin sees the artist as determined by the mythologies of a (male) genius that has been shaped and sustained by art and cultural institutions. And that is the reason why there weren't any Great Women Artists. Simply put: culture did not create the conditions for their existence, so they did not exist.

“(...) the total situation of art making, both in terms of the development of the art maker and in the nature and quality of the work of art itself, occur in a social situation, are integral elements of this social structure, and are mediated and determined by specific and definable social institutions, be they art academies, systems of patronage, mythologies of the divine creator, artist as he-man or social outcast."

Nochlin also points to a very specific reason why women artists could not exist in the history of art: art studies required the practice of nude study, which is still the basis of teaching in academies of fine arts today. Meanwhile, women could not have direct eye contact with nudity. This kind of sensual contact was forbidden for them. Never mind the reasons for this hypocritical morality - let us focus on the result stated by Nochlin.

“(...) the unavailability of nude models to women art students - we have suggested that it was indeed institutionally made impossible for women to achieve artistic excellence, or success, on the same footing as men, no matter what the potency of their so-called talent, or genius."

3 https://www.Artnews.com/art-news/retrospective/why-have-there-been-no-great-womenartists-4201/. Originally appeared in ARTnews, January 1971. 
Such comprehensive rewriting from a new point of view or reinterpretation of the history of art requires a new methodology based on a holistic view of art/culture, i.e. a new research paradigm.

The hypothesis that "(...) the hidden 'he' as the subject of all - is a decided advantage, rather than merely a hindrance of a subjective distortion" assumes an individual genius, which here is a representation of totalitarian power, i.e. one that does not recognize difference, otherness. Thus, it indicates that the answer to the title question lies in the analysis of social, i.e. institutional, conditions of creation and in hidden scholarly predicates. And these are what should be changed. The conditions for creating art, but also social change and, therefore, their correlation, are at the root of a cultural, paradigmatic change.

"Even a simple question like 'Why have there been no great women artists?' can, if answered adequately, create a sort of a chain reaction, expanding not merely to encompass the accepted assumptions of the single field, but outward to embrace history and the social sciences, or even psychology and literature, and thereby, from the outset, to challenge the assumption that the traditional divisions of intellectual inquiry are still adequate to deal with the meaningful questions of our time, rather than the merely convenient or self-generated ones.”

How, then, should the method of proceeding be shaped? In the text by Nochlin, I distinguish two assumptions for the construction of such a methodology.

1 - "(...) probing some of the limitations of the discipline of art history itself." 2 - "(...) by stressing the institutional - i.e. the public - rather than the individual, or private, pre-conditions for achievement or the lack of it in the arts, we have provided a paradigm for the investigation of other areas in the field."

Just as concealing nudity from female eyesight was the cause of the lack of women in art, exposure to nudity is a way to restore their presence. In its assumptions, the festival speaks of nudity in general, without differentiating between male and female nudity. Klodová assumes that nudity in itself, explicitly present in culture as accessible to the sense of sight, constitutes a factor of change. This is because nudity is always liminal. This is also the case in contemporary art because it appears as such, not as representation (1) and because it challenges the institution of art, the very existence of works of art (2). It is especially female nudity that does this, because culture imposed more restrictions on it in the past, which have not been completely overcome (when it comes to male nudity, a similar institutional limitation of gaze concerns homosexual nudity). Generally speaking, however, nudity as such, when it appears in art, falls outside the institutional, i.e. conventional, definition. Danto 
analyzes the Brillo Box and concludes that whether an object that looks like a regular one is an artwork is a matter of convention, or an agreement within the artworld about the meaning and value of that artwork. The possibility of the existence of an artwork-object identical to the regular one is the end of art as mimesis, since it itself constitutes ultimate mimesis. However, Danto continues to consider the artwork-object as only what is available to the institution. Andy Warhol is not an artwork in himself, or perhaps it is his photographic images. A person cannot be possessed institutionally as an object. The body cannot be possessed in this way either. You can have documentation of the action. Ephemeral works, non-objects, non-things, as well as conceptual or live works have no institutional reference - the institution here refers to visual documentation and/or textual description. Institutions treat documentation like artworks, they musealize and commercialize it. However, this does not invalidate the difference from an artwork which is non-existent. An ephemeral work of art exists here and now, it is defined as art and as a meaning in a given context, because in another one this definition and meaning may be different. This is a contextual definition of art formulated by Jan Świdziński. ${ }^{4}$ In this article, I will use the understanding of the term 'context' defined by him. The contextual definition of art invalidates a dispute on the definition of art in the sense that by depriving an artwork of one meaning, it deprives the artworld of one hierarchical system of values maintained by art institutions. Ephemeral works elude institutionalization and thus the stabilization of the hierarchy of values. On the other hand, they willingly submit to contextualization when they are performed in various situational and cultural contexts. In this way, ephemeral art undermines the ability of art institutions to define art and thus undermines the paradigmatic assumptions of both contemporary art and art history (formal and social, and therefore the history of interpretation). Performance art festivals are global and international by nature. They form a global exchange network. And if it is a monothematic performance art festival dealing with the topic of nudity and organized by a woman-curator together with a team of other women and artists at the same time, the criticism of art institutions is even stronger and the argument for a paradigmatic cultural and social change - more powerful.

Women couldn't be artists because they couldn't look at the body. It was like that in history and it was described by Nochlin. However, the avant-garde

4 'Object 'o' assumes the meaning ' $m$ ' in time 't' at place 'p' in situation 's,' in relation to person(s) 'x,' then and only then.” J. Świdziński, Sztuka jako Sztuka kontekstualna. Art as Contextual Art, Remont Gallery, Warszawa 1977. This definition of contextual art has been published many times in various articles. Its writing style is quasi-logical, like in logical proposition sentences. Kosuth also wrote in a similar style. Such a way of describing a relationship with reality is always aimed at an objective and anti-expressionist reading of this relationship, which is to prove that a given statement is true. 
artistic revolution of the modernist period has still not been able to significantly change this situation. And this despite the fact that the classical nude study as the basis of artistic education lost its significance and the avant-garde became the opposition of academism. In the book Inside the White Cube. The Ideology of the Gallery Space, in the chapter "The Eye and the Spectator," Brian O'Doherty sheds some light on this problem. The couple - the Eye and the Spectator - describes a new relationship with a work of art that has ceased to be an illusion of reality and has become reality itself. The picture plane has become identical with the gallery wall, identically 'spotless'; the white cube has become an art space. The process of visual perception is not about building a narrative that completes the narrative of the picture. And, in this sense, it does not co-create art. The gaze has lost its privileged position in favour of direct presence here and now in a given time-space, socio-historical and cultural context. Still, "the Eye" is "he" or "Adam", the one who does not reproduce or recreate, but creates a picture plane that is identical to the white cube. O'Doherty does not explain why the Spectator and the Eye are masculine. One can guess that it is this connection with the social reality, the context, that gives them this gender, not art itself. So, it is a version of this gaze which forbade women to look at the naked model. The new modernist relationship between a picture plane and real space has changed nothing here. O'Doherty writes: "He - I'm sure it is more male than female, arrived with modernism with the disappearance of perspective. He seems born out of the picture and, like some perceptual Adam,

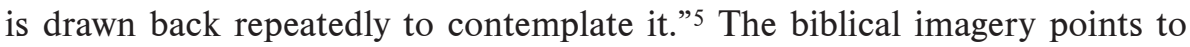
a connection with neoclassicism overcome in the avant-garde. The narrative that defines the character of art based on this metaphor, although transferred into the context, still remains connected with the picture-object, even if it was a whole white cube. This viewer is passive and deprived of causative power because he is deprived of a relationship with the picture from which he could draw strength like a viewer from a mimetic illusion that gives him the illusory power of insight into reality. So, there is no room for agency here, in the sense of a social change or a new social definition of art, that is the re-evaluation that Nochlin calls for.

Such a change becomes possible only when, along with postmodernism, i.e. conceptualism and action (performance art), art as representation disap-

5 B. O'Doherty, Inside the White Cube. The Ideology of the Gallery Space, Lapis Press, San Francisco 1986, p. 39. O'Doherty mentions the names of this He-person: "Who is this Spectator, also called the Viewer, sometimes called the Observer, occasionally the Perceiver?" and Kosuth adds His another name - 'Beholder' - that is the one who acts in the realm of conceptual art. 
pears and "the Eye" loses its driving force or the power to create (re-create) that it had in relation to the picture-illusion or modern picture plane. Conceptualism removes the role of gaze in art, replacing it with meaning and awareness (self-consciousness). As in the case of works of art with quotations or installations made of books by Joseph Kosuth, the text is ready-made, so it is intended to be re/constructed by others. But the work is created in the mind, not in the gaze. Kosuth does not exhibit books, but only their content. Art is according to Kosuth - "making meanings" and not visual forms which are only a "form of presentation" (of these meanings). There has been a shift in the way of creating, but also in receiving and evaluating works of art, in building their hierarchy, shifting from the object and mastery of its making to creativity in making meanings. Art is no longer a visual matter, it is no longer a matter of sight, but a matter of the mind. Non-visual art uses ready-made means. Both the book-object and its content are ready-made. The body in performance art is also ready-made. The naked female body as a ready-made creates semantic conventions and directly answers the question of what art, an artwork and an artist are, without reference to the mediation of visual illusion, mimesis or the picture plane. It does not need an art institution as a source of meaning (as stated in the institutional definition of art by Danto), it is an institution itself. And these institutions (bodies) create a hierarchy of values that evaluate works of art. It is a change of foundations, a "Copernican" or paradigmatic revolution in art, the way it is defined and created, and thus in its reception and interpretation (as demanded by Nochlin).

Inability to create due to gender inequality may be due to the inability to look at the naked body (after Nochlin), or due to social exclusion from the relations governing the space of the white cube and picture plain (after O'Doherty) - and all this changes together with the ready-made. Together with the readymade, the role of gaze in art disappears. The role of gaze in relation to a readymade work, although it is itself a visual fact, ends with the statement of this tautology. Kosuth makes the broadest possible expansion of the ready-made concept. Here are not only ready-made objects but also cultural discourses; not only visual works created in the history of art, but also philosophical, literary and scientific works. I will come back later to the expansion of the ready-made category by Kosuth. Here I will mark one of his conversations concerning the ready-made, when he introduces the 'made-ready' category into his considerations. Here this means taking up such discourses and at the same time their transformation or cancellation in a way, because they are overwritten by his own artistic practice. Thus, they are prepared by the artist, ready to function further in the discourse. The 'made-ready' is also a critical category, as ideas are taken up and developed by others, and this is not a matter of their individualisa- 
tion in the process of creation, but their socialization. ${ }^{6}$ Ultimately, however, as a point of origin, any stated matter of fact is the material of the creation. A look at the ready-made directs us beyond the object of visual perception. Similarly, when the body appears in the role of a ready-made, visual perception directs us beyond the body. A performance made naked as a form of performance art (for the camera or live in public) is a special case. Performance as a form of art based on the artist's psycho-physical condition constructs a special relationship with the recipient who is confronted with his/her own condition on the basis of identification, before developing contextual interpretations.

Performance art is part of the process of changes introduced by conceptualism in art. In performance art, this new relationship between the object and meaning is special. The works of performance art are ephemeral, they are happening here and now. Part of their meaning is the context, developed as contextual art (as understood by Świdziński and mentioned above). In this paragraph, I take up the issue of legitimizing a work of art as a ready-made work - a form of presentation focused on creating meanings. A performance artwork is important in itself. Let us compare the situation of a performer with the situation at the theatre here. A theatrical performance without an audience does not make sense. The presence - the gaze or sight of others - is necessary. The theatre is a machine for transmitting previously established meanings. Like a lecture without students, it makes no sense, as there is no transmission of knowledge. In a performance, the viewer is not necessary. Performance is important even without an audience, because it is a work-artist presentation as the ready-made. Due to the ephemeral nature of a performance work of art, its documentation changes into a work of art. It gains artistic independence, is commercialized and musealized in this role. Therefore, it has the status of an original - it is a primary, not a secondary work, as it usually is the case with documentation. A recorded theatre performance is only documentation and documentation it will remain, and thus it maintains a secondary status to the actors' play on stage. Televised theatre does not become another medium because it does not become independent as a medium with its own artistic means and this is because its relationship with the medium of the performance presented on stage remains unchanged. The status of a ready-made work sets the difference between performance art and theatre. Performance art is not theatre, an actor is not a performer. ${ }^{7}$

6 J. Kosuth, No Exit, in Art After Philosophy and After. Collected Writings, 1966-1990, edited by G. Guercio, MIT Press, Cambridge, MA 2002, pp. 227-234.

7 I know of one case of an attempt to make such a combination - a performance titled Virus, performed by the duo Chief Judge (Karolina Wiktor and Ola Kubiak) at the Rozmaitości Theater in Warsaw, February 11, 2006. The performers acted on stage during a regular 
$*$

Live performance as a ready-made leads us to the issue of the object-subject relationship. The subject is at the same time a ready-made object here. The artist is an artwork. The viewer is watching but is also being watched. The gaze is reciprocated. It does not even have to be, although it is sometimes involved in a performance (which has also become a form on theatre stages). However, his participation does not change the nature of performance as an art based on the psychosomatic condition of the performer, which is still an artistic medium and a basis for interpretation. Hence the issue of objectification in performance requires a comment. The issue of objectifying a person and the body is often discussed in the context of pornography - images and performance. To start with, it must be said that a satisfactory definition of both pornography and art has not yet been created. Moreover, as Simon Fokt argued, in the article Pornographic art - a case from definitions, ${ }^{8}$ there is nothing in the definition of pornography that would allow it to be excluded from art. In other words, it cannot be said that pornography is not an art. This does not automatically mean that it is art, because of the vague and insufficient definition of art. The author uses a type of argumentation based on logical propositions. So, through this linguistic choice, he shows his emotionless approach to the topic under study. His conclusion is very clear: pornographic art can and does exist. Moreover, the existence of pornographic art proves that the definitions of art we use (the discussion was reported in the article quoted here) are wrong. There is a possibility of making the term 'art' more precise and shifting the definition. So, a field is created for the actions postulated by Nochlin. For this purpose, the principle of inclusiveness should be adopted. And indeed, an art historian finds such attitudes and creative assumptions in art practices - from surrealists using the objet trouvé method, through the expanded limit of art media, disciplines and definitions of art, to the postmodern "anything goes" and, of course, Duchamp's art. Such a general solution to the definition dilemma can convince us to trust the artist that what he/she is doing is art, to develop promiscuity in a beholder or a political decision-maker. However, it does not decide about the work, its value and meaning. The principle of inclusiveness is therefore

repertoire performance (so there was no special event). Although the director and actors had been informed about it in advance, the performance caused numerous conflicts with the actors and the audience. The performers eventually left the stage. The experiment failed and, as in the case of an experiment, you have to accept this result. However, repeated attempts to adapt the performance to the theatre would probably result in the creation of such a compromise form. Nevertheless, this crash test of the juxtaposition of performance and theatrical forms showed their incompatibility.

8 S. Fokt, Pornographic art - a case from definitions, "The British Journal of Aesthetics" 2012, 52, no. 3, pp. 287-300. https://doi.org/10.1093/aesthj/ays002. 
a common ground for art and pornographic art, as stated by Hans Maes. ${ }^{9}$ At the same time, it is the principle of inclusiveness that constitutes the basis for the existence of the ready-made in art. Thus, it is in the ready-made governed by the principle of inclusiveness that we find the basis for the existence of pornography as art. As stated above, the body as a ready-made, especially naked, is the basis for reading performance of naked forms as art performance.

Maes directly calls the attempts to distinguish art from porn a 'false dilemma, ${ }^{10}$ thus deepening the argument in favour of the falsity of the existing distinctions, which do not withstand and do not survive in the process of deep analysis. He discusses the falsity of this dilemma where it seems to have been resolved: in the porn industry. For our topic of defining and therefore naming the status of nudity in art, it is important that Maes discusses the term. He uses words and proves that the dilemma cannot be resolved on this level. He calls something pornographic art and something else - just pornographic. The method where one starts philosophizing with the word is also the principle of the beginning of conceptual art that redefines art. The existence of the porn business cannot, however, deny that artefacts, even the products of the business, are discussed as art. In the article cited above, Maes concludes that works of art existing in both categories constitute a quantitatively small collection. How-ever, he hopes that there will be more works in between, but then and only then if we consider these porn business products as ready-made. So, based on the ready-made principle (i.e. on the principle of inclusion into art, inclusiveness, expansion, contextualization), every artefact can be art. In the article Film, Art, and Pornography, ${ }^{11}$ Jacob M. Held similarly considers works that can be porn and art, and indicates the ready-made status of those selected by Duchamp, where a given item can both have a utilitarian function and be a work of art. And this ambivalent status of an object is the key to the meaning of the ready-made as a pivotal theory that inverts the definitions and thus the meanings of things. Each ready-made object/ item can have both its 'own' and other uses. Something can be a work of art, but also an object; it can become the subject of art discourse or be used in practice. Something can be pornography and art, and also pornography or art. The world is your oyster. The dilemma is false when considering the ready-made. ${ }^{12}$ On the

9 H. R. V. Maes, Who Says Pornography Can't Be Art? in H. R. V. Maes and J. Levinson, eds., Art and Pornography: Philosophical Essays, Oxford University Press, Oxford 2012, pp. 17-47.

10 H. R. V. Maes, Art or Porn: Clear Division or False Dilemma? "Philosophy and Literature" April 2011, 35(1), pp. 51-64. https://kar.kent.ac.uk/31448/1/FINAL\%20OUTPRINT.PDF.

11 J. M. Held, Film, Art, and Pornography, in N. Carroll, L. T. Di Summa and S. Loht eds., The Palgrave Handbook of the Philosophy of Film and Motion Pictures, Palgrave Macmillan, (Cham 2019, pp. 721-755. https://doi.org/10.1007/978-3-030-19601-1_31.

12 This argument is quoted after Mimi Vassiliaki, who was first to point to the possibility of solving the 'art or porn' dilemma using the ready-made theory. M. Vasilaki, Why Some Pornography May Be Art, "Philosophy and Literature" April 2010, 34(1), p. 232. 
grounds of art, the theory of contemporary art, post-conceptual art and theoria cum praxi, Kosuth expands the ready-made to the extent that it includes entire cultural discourses and commonplaces. In this way, the results of research in all scientific disciplines are at our disposal, just like works of art history. Any pornography can be art as a discourse. No matter how many works we find in both categories, either through discourse or as a discourse, all porn is included in art. It is a matter of theory and, therefore, self-consciousness. In other words, following Danto, art institutionalizes pornography as art. In this way, Kosuth and Danto, while not dealing with pornography, created a theoretical model for discussing porn as art.

Art to porn relations are even better visible in the field of film, which is not surprising, because the moving picture here is more explicit. In the aforementioned article by Jacob M. Held, the author considers how pornography is defined through the narrative (diegetic) role of sex. However, this is hardly a way of separating pornography from art, especially contemporary art, when both methods used by artists to build projects and curatorial methods of constructing exhibitions are based on narration or, as was said above, an expansion of the discourse. The author's answer is unequivocal: porn can be art. Any nonartistic narrative, when recontextualized in art, turns into art as easily as any visual image, regardless of its nature. It is any syntactic and semantic whole with the status of a story, not just a display for interpretation. However, it should be emphasized that this may be the case again on the basis of the ready-made, when the narrative, whether it be textual, pictorial or a mixture of the two, will be treated as ready-made. The conclusion of the article Film, Art, and Pornography, however, is surprising: all images of sexuality, including explicit sex, appear as a visualization of human nature. Such humanization of pornography ameliorates the value of any such production by refuting the bulk of the argument of commercialism and low cultural value. This is a Freudian response pornography belongs to human nature, it results from it and, at the same time, mirrors and illustrates it. And in the field of art, it is a reference to surrealism, where art is supposed to express libido, to be a way of extracting from us what is in the subconscious, just like during a psychoanalytical session. Surrealism is the imaging of libido, as in the films by the master of erotic cinema, Walerian Borowczyk. The iconography of the body, the gaze at the body and the relationship with the viewer in the case of porn is quite obvious - this relationship must be reciprocal, built on the principle of identification, empathy, compassion or sympathy, when the viewer takes something personally, substitutes their own self for the subject of experience, or empathizes with the artist who builds some kind of self-experience. This, as mentioned above, concerns all the imagery and building a narrative through the body as a direct presence. 
However, the classic scheme of a two-way perceptual relationship is not enough here. In a performance, the viewer complements the object that thus gains subjectivity. In a ready-made model, the interpretation complements the object that then and only then becomes a work of art. In a performance, the viewer's gaze turns an object into a subject. In the process of reception, the artist as a work of art (object) changes into a subject that gains the power of influence, just like a ready-made object gains meaning under an interpretive gaze and begins to participate in the discourse of art. The power of the ready-made is an explanatory power. Annie Sprinkle says in the film Deep Inside Annie Sprinkle, that "I just like having you watch." She is the director and performer here. The artist is an artwork. The film is the documentation of a performance with the status of an original work of art, so it has artistic sovereignty, which is possible under the transmedia principle, i.e. translating one medium into another. Porn functions here just like the ready-made. Her body and her performance are ready-made. In the process of transmedia shifts between media, here from performance to film, the body is depersonalized into an image - documentary. At the same time, the body wants to be seen, it exposes itself to the viewer's gaze. The porn action of Annie Sprinkle as ready-made constructs a narrative and turns into a discourse that can be developed in interpretations. What is individual, becomes social. The gaze of the viewer, by identifying her arousal with his/her own arousal, gives her subjectivity, creates a subjective relationship. There is no distance here. The ready-made is a regular object from the distance. Through the viewers' gaze, Annie Sprinkle's action, her performance for the camera, gives her individuality; hence it is her desire for us to look that creates her as the subject. Contextualization, i.e. the socialization of art in reception, is built here and now, in front of us, in the place of the action which is also a confrontation of the viewer with his/herself, his/her self-awareness of his/ her own psychosomatic condition and, at the same time, with the social and therefore critical condition.

Let us now consider, in the context of the 'pornography to art' conversation, the definition of nude images in naturist photographs as a piece of evidence for the functioning of an entire iconosphere of nudity ${ }^{13}$, so not only art. In photography, nudity is depicted directly, mirrored, as it is a mimetic medium. Naturist nudity legitimizes or justifies this image as one of the images of sexuality. Eroticism or awareness of libido appears here as part of human nature. An example is Lotte Herrlich (1883-1956), a German photographer regarded

13 The iconosphere - a term coined and introduced into art history research by Mieczysław Porębski. It refers to a whole array of particularly organized visual information channeling and conveying, or transferring a particular range of information distributed in the social sphere under particular culture conditions. 
as the most important female photographer of German naturism (Freikorperkultur - FKK) in 1920s. Then the Nazis banned FKK. Her series of photographs in nature were frequently stylized and they were also often reportage, going beyond the style of atelier photography, and therefore having more freedom in composition, random. They are neither personalized, nor do they constitute artistic creations, stories about themselves. They are then like a performance for photography. Their incorporation into art is made on a ready-made basis. Their goal of creation is not art, but the promotion of a certain lifestyle. So, the goal is social. They become art not only because of their institutionalization in galleries and museums, but also inclusion in the discourse. Another example from the field of photography are Larry Clark's images of teens having sex included in The Brooklyn Museum Collection: The Play of the Unmentionable, 1990, an exhibition by Kosuth (as the curator-author because it was an installation-exhibition). These are reportage photographs, but also slightly stylized, posed, showing performance for the camera. These teens' life stories have been told - the narrative is Larry Clark's goal here. But as ready-made images, they describe the history of image in art, image that redefines art in context, creates art through discourse, which justifies their inclusion in an art exhibition. It is the task of these photographs at this exhibition to question the definition of art. Their explicit sexuality, like FKK's naturism, takes part in another game in which the viewer's gaze plays a constitutive role. In this case, it is a gaze at the naked body. The body is a game changer - from a ready-made photo to discourse. The goals of photography (promotion or reportage here) cease to play their role and we start talking about art, censorship, freedom and politics. Nudity proves once again to be a critical factor par excellence.

Each edition of the FNAF festival has a leading theme, inscribed in the trends of culture. So, the assumed nudity (artistic monothematicism) was a means used to take up various topics, build a narrative, participate in discourses. It was nudity in context.

The first festival was entitled Nahota hédonická a nahota kritická (Hedonic nudity and critical nudity) and it was a Czech edition, as the only foreign participant was Dariusz Fodczuk (PL). The two key words: 'hedonism' and 'criticism' characterized two opposing approaches to nudity: active and passive, respectively. Part of this festival was a professional erotic photography session in which Vlastimil Kula specializes. The naked bodies of two models contrasted with the post-industrial interior. However, this photo session was held in public and the participants, artists and audience could play a creative role in it. The audience became more and more active over time, taking control of the photo session. Thus, there was an active and passive role exchange, which is 
very different to Spencer Tunick's method of stylized body arrangements. The festival's title was to be reflected in the festival's program schedule divided into hedonistic and critical parts. However, with the exception of Vladimir Havlik, everyone else declared to be related to hedonistic nudity. Both the photo session of erotic photography and letting the participants choose the program were experiments carried out by Klodová. For her as the curator, an academic teacher at FAVU Brno, Body Design Studio (Tělový design atelier), the festival is a kind of scientific program based on combining artistic and research methodology. ${ }^{14}$ The research questions of this festival edition are: the use of the body in various ways, more or less erotic or pornographic (to what extent does our imagination draw from the patterns of pornography?). This is another experiment with nudity carried out by Klodová. It includes both artistic and social aspects. It is a mirror placed in front of the imagination triggered by the subject of nudity.

The theme of the second festival was Národni nahota (National nudity). Performance art is international by definition. Performers have to travel. Performance cannot be done otherwise. For the same reasons, performance art is multicultural. It complies with the 'glocal' principle - connects the local and global, artists and cultures. Performance festivals are everywhere. Moreover, if performance is not present somewhere, it is a sign of a lack of cultural freedom. A regime may forbid performance art and artists living in such regimes use performance as a means of individual freedom and cultural criticism, especially when it is done naked. Many regimes seemingly care about public morality. Nudity challenges them. Nudity brings freedom and naked performance is a particularly tender indicator of freedom. This inherent feature of nudity was used by Klodová and made the research subject of the edition. The invited artists, met by her at various festivals, discussed the approach to nudity in their countries. Since this edition, conferences have become a permanent element of the festival, which indicates their research character. Another element of this type are workshops that are educational, as well as experimental. For Klodová, this is another means of changing the festival into a cultural research laboratory. Everyone, including the audience, lived together at the Divus factory during the festival. The workshop was therefore an instance of team work, carried out as if in research teams. This, again, is a method borrowed from academic practice.

The third festival was entitled Mladá a stará nahota (Young and old nudity). The theme referred to performance as an old genre with its own history. So, it is like a body that has signs of the times on it. But it has a very young soul.

14 http://htm.divus.cz/praha/en/page/?uri=f-n-a-f\&id=100 - Lenka Klodová on the first edition of the festival. The text published on the Divus website. 
So, it is a living art genre. During this edition, a naked choir gave a concert, which indicates the intermedia nature of the festival. There was a conference on nudity - a permanent component of the festivals that turns them into art and research projects.

After this edition, the festival moved to Prague, to Kasárna Karlín (former barracks in the Karlin district of Prague). ${ }^{15}$ The title of the fourth edition was Ženská nahota (Female nudity). By coincidence, the festival took place at the time when the social campaign 'me too' began. Its cultural significance was based on the visibility of the other side of patriarchal culture - taking into account the female point of view. This shift is part of a broad wave of cultural change. In art, it is expressed in the reinterpretation of the history of art, but also in works and curatorial decisions taking into account the principle of gender balance. The festival has become a voice, but also an exemplification of this kind of cultural re-evaluation.

Nahota a bolest (Nudity and pain). The body is organically linked to pain, writes the curator of the fifth edition of the FNAF festival. Critical art often deals with pain as a somatic and psychological trauma. As in the body relationship, erotic pleasure is a transgression, so pain is also transgressive. Pain is critical, it calls into doubt and at the same time is transgressive, it transcends sensual pleasures towards individual experience; pain cannot be aestheticized because it loses its strength. Performance (body art) uses the body as an artistic medium and body fluids as material. The opening of the surface covering the body is a gesture of transgression of the classical aesthetics of beauty in favour of objectification of the body, just as cutting through the surface of the canvas (by Lucio Fontana) changes the painting into an object and contradicts the picture-representation.

Striptease (male or female) was often taken up in the performances of the Festival of Naked Forms as a critical reference to the commercialization of the body. Striptease took place during the 2nd, 3rd and 4th edition. The curator calls it 'FNAF escort.' However, the striptease was held at an unusual time, in the morning. Klodová always makes sure that these experimental laboratory events follow a course that is inconsistent with their regular practice, so that they are brought out of routine and subjected to critical scrutiny. The Shibari show (bondage art) made a similar sense. Striptease and bondage, like pornography, are cultural practices that create context for the actions of performance artists. But they also create it for the public who must revise their view of what is art and what is not, work through its definition. Here, art is confronted with non-art, thus opening art to its new definitions, as well as to cultural narratives that are shaped anew. FNAF fashion has a similar character - fashion shows,

https://kasarnakarlin.cz/cs. 
by definition, cover the body and thus seemingly contradict the monothematic assumption of the Festival of Naked Forms. However, at the same time, fashion can be understood as a correlate of the body, not as autonomous fashion design detached from the relationship with the psycho-physical condition of a human, but also as a social phenomenon, as the presented fashion was an alternative to mass production. This is why fashion understood in this way has become a constant component of the festivals. All these elements incorporated into the structure of the festival have turned it into a field of artistic and contextual experiment.

Nudity and the Future - this was the theme of the 2020 edition. It took place in the conditions of the progressive Covid pandemic and increasing restrictions imposed on public life. Previously, part of the festival was held in a small village in the Sudetes Mountains (FNAF Sudeten), so without professional audience, which gave the festival the character of a workshop or a lab where a team of specialists conducts an experiment. Here we have an experiment with the naked performance form, i.e. with oneself as a material, but also with locals. The freedom of creation was liberated thanks to the relative isolation from the gaze of the public, critics and other professionals. Karolína Kohoutková proposed a collective action of the participants - Movement of the precious. It was a form of performance for photography, part of which took place at night, when naked participants let themselves get caught in photo traps placed in the forest. The performance allowed for an extremely interesting way to create performance documentation which acquires the status of a primary artwork (and not a secondary one in the form of a document).

Part of this year's edition of the festival at Karlín Studios, held in a gallery and a courtyard, was again limited in terms of the number of foreign visitors. But because life is moving to the Internet, the restless curator Lenka Klodová created an online edition of the FNAF Home festival - online performance. Documentation from previous FNAF editions is also available on the website. ${ }^{16}$ In Kasárna, performances took on several forms. As the bars in Kasárna were still open and the weather was favourable, one of the forms was to take advantage of the situation and act in situ among the audience (Denis Bastuga working in a duet with his partner). Another form of performance was acting with the use of one's own body and nudity, subjected to a violent experience (Martin Zet, Adam Zduńczyk). However, it was the she-performers' use of the body that opened up the possibility of creating new meanings in line with Nochlin's assumption of comprehensive change, deconstruction of patterns and stereotypes of culture, and their re-evaluation. I mentioned earlier the performance by Darina Alster who raised a banner as a heroic sign, a call to action. And she pointed out the

16 http://www.fnaf.fun/. 
place of the action - the body. The body, when gradually covered with a text, forces a gaze and makes you watch it in order to read the text. The text symbolizing Sofia was combined with her sensual body. Saydie Vell and Alica Minar used a form of performance based on the erotic or pornographic image of the female body, referring to the pattern from mass culture and sex industry, or rather our images generated by them. So, both these imaginations and the images created by the she-performers were used just like a ready-made. They played a game with the image, but also with the viewer's libido. The image is exposed to our gaze, which turns into an interpretive, critical gaze when we consider it ready-made and link it with the context. The gallery situation additionally institutionalizes this image of sexual desire as art. As in Annie Sprinkle's call to watch in the aforementioned film, the art presented in the gallery is a call for an interpretation that goes beyond erotic emotion, but by no means invalidates it. The viewer's libido was used here as a vehicle for data transfer between the output image, porn ready-made and the work in art (culture) relations. In turn, Kača Olivová and the duo NEWkus (Bára Smékalová and Sara Wollasch) chose a form of performance based on the destruction of the image of nudity, a-aestheticization. Olivová presented love as a fight depicted by wrestling with a partner in the performance, while Newkus (NEWkus means 'bad taste,' but through the use of upper case letters it becomes ambiguous and may mean 'new taste') focused on self-destruction of the image. Body-ready-made changes here into a symbol, so the relations with reality are weakened and the 'beholder' in the process of reception is first forced to look for meanings existing in his/her vocabulary, rather than to create new meanings.

In the last edition of 2020, the problem of the future of nudity was raised. Nudity tests culture and this test will continue in the next editions of the Festival of Naked Forms, as well as in the projects, research and academic teaching of its curator, Klodová. This edition was a breakthrough in the sense that while in the previous festivals the issue of nudity was addressed with reference to selective problems, now its general role has been named; its creative force and its power of agency have been identified. So, a look to the future appears, i.e. the awareness of the need to design long-term effects of practicing the art of naked forms. Let us remember that the curator has always taken care to build a theoretical reference for each edition of the festival. So, she is fully aware of its effects that arise in the perceptual relationship. As in the avant-garde model of interaction with the viewer, the shock was socially subversive, i.e. critical and heralded a social change. ${ }^{17}$ The shock experience changed the viewer's attitude - when they did not get what they expected from art, they reacted

17 P. Bürger, The Theory of the Avant-Garde, translated by M. Shaw, Manchester University Press, Manchester 1984. See particularly pp. 80-81. 
with rejection, just like nudity is rejected today by classifying it as linked to pornography, i.e. a reference model of mass culture, but here incorporated into art via the ready-made. Culture in every epoch has dealt with nudity and that has essentially defined it. And so - as Klodová rightly assumes - it will be in our culture dominated by digital technology, biotechnology and AI technology that increasingly discreetly interact, reducing the cultural influence of religious metaphysics. The body is the seat of intelligence, not the soul. God has died, man was born and this is "gay science" (after Friedrich Nietzsche). The human has acquired subjectivity towards the world and seeks its sources in themselves, in their self-awareness and not outside themselves in religious metaphysics. The human speaks of themselves in terms of psychosomatic unity, as it is in performance, where a naked form is a case of particularly acute self-awareness. In this context, the naked body can be summarized in linguistic terms, the new language we use to talk about the human in a non-metaphysical way. Nudity is a sign in a semiotic sense. The body can be considered here in signifié/signifiant relations. The body, then, is a signifiant - a visual sign which, appearing in a cultural realm, in art, begins to mean, define and create meanings as a signifié. It is the role of nudity for the future - define the human being in cultural practices such as art. As a new language, nudity challenges the old culture and builds a new culture.

The relationship with social media shows the critical and subversive power of nude performance forms. Facebook, the most popular social communication channel, is useless here. Nudity distances the civilization of media corporations, shows its limitations. Nudity is not possible on Facebook. FB is not able to absorb this festival and thus its message. It is finite as a place of freedom and makes use of "disciplinary power" (after Foucault). The naked body, common to all, natural as one's own, is here socially excluded from corporate pictorial culture. The future of nudity is a post-media and post-corporate future. Art can create new channels of communication, even the academic one, because the teaching tradition is based on nudity. Heroic nudity, which is now complemented by nudity brought by women's gaze at the nude study, is part of nature and self-consciousness, and not of patriarchal culture, but in opposition to it. A harbinger of such an approach to the naked body is the Body Design studio in Brno, at Brno University of Technology, Faculty of Fine Arts, run by Klodová. ${ }^{18}$ For her, the festival, i.e. curatorial practice, her own artistic practice and the teaching practice of educating young artists (she-creators) are related. The Future of Nudity is the result of this work that we will see in the near future.

18 https://www.favu.vut.cz/en/studios/body-design. 


\section{Conclusion}

Nudity is a territory of art that nobody wanted to develop in the times of modernism / postmodernism. It was a double risky subject: traditional and academic on the one hand, and a revolutionary icebreaker on the other hand. Nothing in the middle, juste milieu, that would allow one to practice art and be a socially recognized and respected artist. In the tradition of European culture derived from Antiquity, nudity is an attribute belonging to gods and heroes. Christianity, which was fighting this European tradition, deprecated nudity and repressed it in the iconography of art. The modern period brought nudity back to culture in an ancient costume. Modernist avant-garde art is self-referential. The naked body is an excuse and it is not important in itself. In the 1960s, nudity became a means of combating the social traditionalism of the "middle class", where the body and eroticism were hidden, constituting the sphere of secret. It is this tradition that forbade a woman's gaze at a naked body, as described by Nochlin. So, when the naked body appears as art, as a work of art in itself in performance art based on the assumptions of conceptualism, this changes the definition of art and a work of art: from representation to the ready-made, and at the same time such art as made ready becomes a vehicle of contextual, i.e. cultural change, assigning a different place to the female subject. It is to break the Christian anti-Ancient phobia of the naked body, by forcing it to be accepted in society, as well as validating and justifying it in galleries, and museums of contemporary art, i.e. institutionally. At the same time, the development of pop culture, where eroticism was exposed, found use for nudity as pornography (note that early pornography is based on patterns of academic art with a neoclassical provenance, and thus - then - bourgeois taste, that is, a popular version of high culture). Popularization, which equates to the commercialization of nudity, made it cease to be an iconographic model useful in critical art, become recuperated and deprived of critical power. Therefore, nudity must find a new form for its presence in art. This is direct nudity, as in live performance, or film and photography. The Festival of Naked Forms introduces nudity into art after its deprecation in post-avant-garde culture and recovers nudity for critical art. The possibility of gazing at the nude is restored; it could be sensual, erotic, beautiful or the opposite - it is always ready-made. Nudity as the ready-made directs the reception process beyond itself, which allows it to be included in art, to build a contextual narrative or a discourse in which it participates. However, it still remains a form of presentation. As a form, nudity builds an iconosphere representing new human relations, in the sense of 'posthuman' by Rosi Braidotti. It is not the nature-culture opposition that is visualized here, but the human being as one of the global living organisms in the structure of life on the planet, functioning on the principle of equality of human and non-human subjects. 
This represents the broadest extension of Jacob M. Held's position from the quoted article Film, Art, and Pornography which saw the representation of nudity as part of nature. Taking this topic as the leading one in the FNAF festival is a way of building a new form for a new discourse of inclusiveness.

"Finding an adequate language for post-anthropocentrism means that the resources of the imagination, as well as the tools of critical intelligence, need to be enlisted for this task. The collapse of the nature-culture divide requires that we need to devise a new vocabulary, with new figurations to refer to the elements of our posthuman embodied and embedded subjectivity." 19

The discussion on borders and relations of porn to art is a discussion on the definition of art. A change in the definition of art is a cultural one and the inclusion of nude forms changes culture, as in the 1960s. However, it also changes the gender of culture in the process of its interpretation, following Nochlin. Nudity has great critical potential, as exemplified by the actions of the Vienna Actionists. The most radical artist in the group, Otto Muehl, founded a commune where the means of departing from social norms were openness to nudity and sex. ${ }^{20}$ With these measures, he built the harshest criticism, accusing the (Austrian) society and culture that led to the Holocaust. The same criticism is expressed by photo-images, actions for the camera by Rudolf Schwarzkogler depicting pseudo-medical experiments, or by the action field as from a torture chamber in Günter Brus's works. The actions of the Vienna Actionists, especially Muehl, present nudity as revealing human nature deprived of a veil of culture that has failed because the Holocaust was possible. Nudity serves to overcome the nature-culture opposition by contradicting the latter, creating a work that is as non-cultural and non-humanistic as possible, and does not fit into any cultural scheme, showing the human detached from culture and immersed in mental illness, devoid of rationality, i.e. humanistic rationalism. The actions of the Vienna Actionists reject culture as a whole, possibly replacing it with some ritual created for the needs of art, partially transforming Christian rituals, as in the case of Hermann Nitsch's actions. A redescription of culture, where the human is involved in natural processes, creates an ecosystem of horizontal equality and does not build a hierarchy of subordination to power. Naked forms transform a hierarchical and patriarchal culture into a culture of equality. Its validation and justification rest in the nature of deep ecology, not just in law and, in this sense, it is a post-democratic culture. At the same time, which is demonstrated by the actions of the Viennese Actionists, the political nature of these actions, although undoubtedly intended, is not sufficient to present the concept of nature expressed here in the form of a naked body. It is

19 R. Braidotti, The Posthuman, Polity Press, Cambridge, UK 2013, p. 82.

20 See documentation on https://ubu.com/film/muehl. html. 
because a commentary, or review is an act of rationalization and the strength of libido is intangible, as it is proved by the works of art of surrealists who wanted to illustrate it.

"Oslava lidské nahoty" - Darina Alster wrote about the festival, ${ }^{21}$ which is translated as "Celebrating human nudity" - its expression, positive emotions, but also catharsis and distance to everyday life. The six editions to date prove the importance of the medium of nudity in critical cultural research conducted through art and in the field of art, entering the most modern approach - extended eco-humanism and its challenges. Therefore, the essential character of the festival goes far beyond the form of naked performances.

\section{BIBLIOGRAPHY:}

100 Artist's Manifestos From the Futurists to the Stuckists (2011), selected by A. Danchev, Penguin Books.

Świdziński Jan (1977), Sztuka jako Sztuka kontekstualna. Art as Contextual Art, Warszawa: Remont Gallery.

O'Doherty Brian (1986), Inside the White Cube. The Ideology of the Gallery Space, San Francisco: Lapis Press.

Kosuth Joseph (2002), No Exit, [in:] Art After Philosophy and After. Collected Writings, 1966-1990, edited by G. Guercio, Cambridge, MA: MIT Press, pp. 227-234.

Fokt Simon (2012), Pornographic art - a case from definitions, "The British Journal of Aesthetics", 52, no. 3, pp. 287-300.

Maes Hans R. V. (2012), Who Says Pornography Can't Be Art? [in:] H. R. V. Maes and J. Levinson, eds., Art and Pornography: Philosophical Essays, Oxford: Oxford University Press, pp. 17-47.

Maes Hans R. V. (April 2011), Art or Porn: Clear Division or False Dilemma? "Philosophy and Literature", 35(1), pp. 51-64.

Held Jacob M. (2019), Film, Art, and Pornography, [in:] N. Carroll, L. T. Di Summa and S. Loht eds., The Palgrave Handbook of the Philosophy of Film and Motion Pictures, Cham: Palgrave Macmillan, pp. 721-755.

Vasilaki Mimi (April 2010), Why Some Pornography May Be Art, "Philosophy and Literature", 34(1), pp. 228-233.

21 http://www.polipet.cz/zapisnik/oslava-lidske-nahoty-ohlednuti-za-festivalem-nahych-foremdarina-alster/ - a description of the first festival. 
Bürger Peter (1984), The Theory of the Avant-Garde, translated by M. Shaw, Manchester: Manchester University Press.

Braidotti Rosi (2013), The Posthuman, Cambridge, UK: Polity Press.

Internet sources

http://htm.divus.cz/praha/en/article/alfred-kubin-a-few-notes-inspired-by-the-exhibition. https://www.ubu.com/historical/breton/Breton-Andre_First-Manifesto-of-Surrealism_1924.pdf. https://www.Artnews.com/art-news/retrospective/why-have-there-been-no-great-women-artists4201/. https://kar.kent.ac.uk/31448/1/FINAL\%20OUTPRINT.PDF. https://doi.org/10.1007/978-3-030-19601-1_31. https://doi.org/10.1093/aesthj/ays002. http://htm.divus.cz/praha/en/page/?uri=f-n-a-f\&id=100. https://kasarnakarlin.cz/cs. http://www.fnaf.fun/. https://www.favu.vut.cz/en/studios/body-design. https://ubu.com/film/muehl. html.

http://www.polipet.cz/zapisnik/oslava-lidske-nahoty-ohlednuti-za-festivalem-nahych-forem-darina-alster/.

\section{NAGIE FORMY - WYZWANIE KULTUROWE (streszczenie)}

Punktem wyjścia artykułu jest Festival of Naked Forms, który jest organizowany przez Lenka Klodova w Pradze (i okazjonalnie w innych miastach). Kuratorka nadała festiwalowi charakter monotematyczny. Dotyczy on nagości w sztuce performance, a więc formie na żywo. Festiwal odbywa się co roku, od 2016. W tym czasie na festiwalu została zaprezentowana ogromna różnorodność form performance, środków artystycznych, hybryd medialnych. Dokumentacja festiwalu stanowi podstawę badań nagiej formy w sztuce na żywo. W metodologii interpretacyjnej naga forma została powiązana $\mathrm{z}$ formami prezentacji libido oraz 'zasady przyjemności', a także aspekt wizualności dzieła sztuki i roli 'spojrzenia' w tak specyficznym dziele jakim jest dzieło sztuki performance. Punktem odniesienia są zarówno sztuka surrealistyczna jak i po współczesne relacje sztuki wobec pornografii. W konkluzji została wskazana subwersywna, rzucająca wyzwanie czyli polityczna, siła nagich form i ich zdolność dokonania zmian w kulturze.

Słowa kluczowe: performance art, pornografia, spojrzenie, pleasure principle, posthumanizm, gender, Festival of Naked Forms, Lenka Klodova

Łukasz Guzek, PhD (after habilitation), professor at the Academy of Fine Arts in Gdańsk. Born in 1962 and current employed at the Academy of Fine Arts in Gdańsk. In his work, he combines research in art history with art criticism and curatorial practice. Since 2009, he has been the editor-in-chief of the scholarly journal "Art and Documentation" (www.journal.doc.art. pl). In 2017, he published a book entitled Reconstruction of Action Art in Poland which provides comparative analyses of and research methodologies on performative works of art. 